Marsh Birds, 1926, p. 311) have previously reported the perching of a Sora on a tree limb and consider this behaviour to be most unusual for this species.

Ed. Note: See also the report by T. E. Randall (Blue Jay, 20:116) of a Sora nest in a willow bush.

\section{QUERY RE: RECORD OF WESTERN TANAGERS AT LITTLE MANITOU LAKE, AUGUST 14, 1963}

The Editors are grateful to vigilant Blue Jay readers who read published records carefully and help to evaluate them in the light of their personal experience. We thank Mr. R. D. Symons, with his long association with Saskatchewan birds, for asking us to review the record of a flock of Western Tanagers at Little Manitou Lake, August 15,1964 , which we printed in a recent issue of the Blue Jay (22:53, June, 1964). Mr. Symons feels that these birds might have been Red Crossbills, and offers the following reasons:

"1. Between August 5 and September 1,1963 , we had a flock of five Red Crossbills on the lakeshore at Silton. They fed in poplars in exactly the same way and on the same beetles. They also visited our sunflowers at the end of August.

"2. Red Crossbills are in the habit of occurring in flock of from a few individuals to several family groups at almost any season of the year, and in the most unexpected places. For example, from my records: "In poplars at Cut Knife, Sask., August, 1933 (White-winged Crossbills)"; "in poplars at Wood Creek, Renown, July, 1924 (Red Crossbills)". Now, Renown, Watrous (Little Manitou Lake) and Silton are in the same general area, and exactly similar habitat.

" 3 . The difference in size between the species is not really noticeable without some basis for comparison.

"4. The difference in bill, except at a few yards, is not easy to see. At 20 feet with field glasses, and at six feet without, my wife had difficulty in seeing the crossed bill. Her eyes are not trained, it is true; but she looks at birds a lot.

"5. In coloration (except at height of breeding season) the differences, again, are not great. The general greenish to yellowish plumage of the females is somewhat similar. Either species might show, in adult males, more or less red at that time of year. There is the matter of wing bars. These might or might not be quite noticeable. They occur on the Tanager, but not on the Red Crossbill, and are fairly plain on the White-winged Crossbill (see the above occurrence at Cut Knife).

"6. General habits. Generally speaking, both species feed quite silently. In spring the male tanager, of course, utters his simple chirruped song. Both species are fairly sluggish in movements.

"7. I have been fairly familiar with the Western Tanager in the Peace River parkland and east to Meadow Lake. Taverner's description of (all but spring male) Western Tanager as "a dull, greenish, sparrow-like bird" is good, but could also be applied to (all but a spring male) either of the crossbills.

"8. I know the Watrous area to be within the normal (if not regular) range of the crossbill. I think it is rather far out for Tanagers, and I have never personally seen tanagers in such a "flock" as described.

"9. Habitat. I would not expect to see tanagers in such meagre woodland as at Little Manitou. I have always found them in heavy poplar or mixed woods with trees averaging at least 60-75 feet in height."

Reviewing the note on Western Tanagers at Little Manitou Lake gives the Editors an opportunity to make another comment. The article called attention to the range of dates for previous documented records of the Western Tanager in southern Saskatchewan as extending from May 13 to May 28. A recently published record of a spring male at Tullis on May 22, 1940, also falls within these dates (see J. Frank Roy, An Introduction to the birds of the Elbow, Regina, Saskatchewan Natural History Society, 1964). 